\title{
PANKREATOR - WSPÓLNY PROJEKT POLSKIEJ AKADEMII NAUK BIBLIOTEKI GDAŃSKIEJ I INSTYTUTU KULTURY MIEJSKIEJ W GDAŃSKU
}

W

ramach projektu Pracownia Nowych Mediów, dofinansowanego ze środków Ministerstwa Kultury i Dziedzictwa Narodowego, realizowanego w 2016 r. przez Instytut Kultury Miejskiej we współpracy z PAN Biblioteka Gdańska, pracownicy obu instytucji opracowali wspólnie materiały edukacyjne inspirowane zbiorami cyfrowymi biblioteki. Proces opracowywania tych materiałów i sama realizacja dostarczyła wielu doświadczeń, satysfakcji i była bardzo efektywna.

Skupiono się na PAN Bibliotece Gdańskiej ze względu na jej bogatą i różnorodną kolekcję, której potencjał do ponownego wykorzystania jest ogromny. Biblioteka posiada w swoich zbiorach wszystkie rodzaje druków, od średniowiecznych manuskryptów przez kolekcję druków muzycznych po dwudziestowieczną prasę Wolnego Miasta Gdańska. Inicjatorki projektu: Karina Rojek (IKM) ${ }^{1}$

${ }^{1}$ Absolwentka Historii Sztuki na Uniwersytecie Gdańskim. Koordynatorka Medialabowych projektów Instytutu Kultury Miejskiej: Akademia Nowych Mediów, Pracownia Nowych Mediów, Miasto: szukam!. Redaktorka serwisu popularyzującego domenę publiczną oraz biblioteki cyfrowe - www.szukamy.org. Koordynatorka projektu PANkreator. Angażuje się w upowszechnianie korzystania z otwartych zasobów w edukacji oraz w propagowanie idei otwartych instytucji kultury. Współtwórczyni projektu „wyszukane”pamiątki z Gdańska inspirowane utworami z domeny publicznej. 
oraz Marta Pawlik-Flisikowska (PAN BG) ${ }^{2}$ wyszły od ogólnego pomysłu przygotowania materiałów edukacyjnych, które spopularyzują korzystanie ze zbiorów cyfrowych. Już w tym ogólnym założeniu można dostrzec dwa cele: edukacyjny i promocyjny, tj. tworzenie wizerunku biblioteki jako instytucji nowoczesnej i otwartej.

Pracę rozpoczęto od zaproszenia do zespołu roboczego osób o różnych kompetencjach - tak aby korzystając z metod pracy design thinking móc jak najefektywniej wypracować najlepszy pomysł. Zaproszono bibliotekarzy, polonistów, programistów, ekspertów od prawa autorskiego, otwartych zasobów, a spotkania prowadziła specjalistka od design thinking. Podczas pracy skupiono się na użytkownikach. Stworzono grupę docelową, do której chciano dotrzeć w pierwszej kolejności. Zastanawiano się nad korzyściami jakie można im zaoferować. Efektem kilkudniowych spotkań była koncepcja serwisu internetowego, który umożliwiałby samodzielne przygotowywanie gifów na bazie udostępnionych tam grafik. Zbiory w serwisie byłyby wyselekcjonowanym zbiorem atrakcyjnych wizualnie ilustracji: grafik, zdjęć, map, rycin itp. Dodano by również merytoryczne opisy i linki odwołujące do źródeł. Serwis roboczo nazwaliśmy - Ożywiacz. O konsultacje tego pomysłu zwrócono się do trójmiejskiej społeczności Koduj dla Polski. Konfrontacja pozwoliła zweryfikować wstępne założenia. Okazało się, że wyobrażenia o możliwościach użytkowników sieci okazały się wyolbrzymione. Sam pomysł oceniono jako dobry, ale realizacja i późniejsze użytkowanie jednoznacznie zostało ocenione za wątpliwe, ponieważ robienie dobrych gifów to umiejętność godna najlepszych grafików, a podstawowe animacje na niskim poziomie nie będą dla potencjalnych użytkowników satysfakcjonujące - nie będą więc chcieli ich robić. Taki feedback był dla organizatorów jak kubeł zimnej wody - natomiast patrząc z perspektywy - niezbędny. To też pokazuje jak ważne są testy, prototypowanie produktów i konsultacje z szerokim gronem odbiorców. Szczerość, ale i konstruktywna krytyka ze strony osób działających w Koduj dla Polski, przekonała nas do podjęcia współpracy i regularnym uczestniczeniu w spotkaniach. Spośród stałych członków tej społeczności znalazły się takie, które dołączyły do projektu PANkreator. Byli to graficzka, programista, fotograf. W trakcie kolejnych spotkań pierwsza koncepcja została zmieniona i uproszczona. W nowej formule również zaplanowano serwis internetowy,

${ }^{2}$ Historyk. W PAN Bibliotece Gdańskiej prowadzi Pracownię Fotografii, tzn. gromadzi, opracowuje i udostępnia (również na platformie cyfrowej) dawne zdjęcia Trójmiasta. Ponadto zajmuje się promocją Biblioteki. Jej zainteresowania i działania promocyjne skupiają się głównie wokół social media. 
ale oferujący gotowe gify przygotowane na bazie zbiorów biblioteki, które użytkownicy będą mogli swobodnie wykorzystywać w mediach społecznościowych, prezentacjach lub jako ilustracje własnych treści. Wątek opisów i linków do źródeł pozostał bez zmian i przybrał formę bloga eksperckiego. Bardzo ważnym efektem współpracy z KdP był udział Organizatorów PANkreatora w hakatonie kulturalnym w 2016 r. w Warszawie. Dzięki temu projekt zyskał kolejne narzędzie - bota internetowego, który codziennie publikuje w serwisie Twitter i Facebook losowy zbiór z zasobów PAN BG udostępnionych w Pomorskiej Bibliotece Cyfrowej. Sam bot PAN Kreator został przygotowany w ciągu 2 dni przez programistów: Piotra Gołębia i Weronikę Sikorską. Zasady hakatonu warunkowały publikowanie przygotowanych narzędzi na otwartych licencjach. Kod bota jest publicznie dostępny w sieci: https://github.com/vevurka/pbc. PAN Kreator publikuje automatycznie i jest w zasadzie bezobsługowy, natomiast moderowanie jego postów skutkuje większym zaangażowaniem ze strony odbiorców i nowymi polubieniami. Od momentu powstania bota i IKM, i PAN BG korzystają z tego narzędzia traktując je jako dodatkowy kanał do komunikacji. W obliczu planów biblioteki, aby w jeszcze większym stopniu udostępniać swoje zbiory ikonograficzne przez specjalnie przeznaczoną do tego stronę, rola bota może okazać się jeszcze bardziej potrzebna i uzasadniona.

Fakt przygotowywania takich narzędzi (biblioteka gifów, bot internetowy) był odbierany w środowisku jako innowacyjny. Gify i bot stały się częścią większej strategii promocyjnej zbiorów biblioteki. Dodatkowo wypracowana formuła współpracy z instytucją kultury oraz organizacją non-profit, doświadczenie jakie zdobyliśmy przy projektowaniu serwisu, a także partnerstwo i współpraca z trójmiejskim Hackerspace'em są dla nas i uczestników projektu bezcenne. Zachęcamy inne biblioteki do wykorzystywania tego pomysłu, a użytkowników do korzystania z gifów i informacji ze strony. Mamy nadzieję, że gify będą w stałym użyciu i zaczną żyć swoim życiem. 
